Bulletin of Pharmaceutical Sciences
Assiut University
Website: http://bpsa.journals.ekb.eg/
e-mail: bullpharm@aun.edu.eg

\title{
PREDICTORS OF HCV SEROCONVERSION AMONG END-STAGE RENAL DISEASE PATIENTS IN HEMODIALYSIS UNIT
}

\author{
Fakhara Bukhari $^{1}$, Ahmad Khan ${ }^{1}$ and Tahir Mehmood ${ }^{* 2}$ \\ ${ }^{1}$ Department of Pharmacy, Quaid-I-Azam University, Islamabad, Pakistan \\ ${ }^{2}$ SNS, NUST, Islamabad, Paksitan
}

\begin{abstract}
Background: In patients under dialysis, blood borne infections remains one of the mostpublic causes of morbidity, hospitalization and death. Among dialysis patient's long-term hemodialysis (HD) therapy, frequency of blood transfusions and multiple blood transfusions enhance the risk of acquiring blood-borne infections.

Objective: The aim of the study was to identify predictors for HCV seroconversion in HD patients.

Method: Prospective observational study was conducted on 173 Chronic kidney disease (CKD) patients undergoing HD. Anti HCV antibody testing was accomplished at the start of study and every 2-3 months subsequently. To identify seroconversion, patients who were sero-negative for HCV were monitored.

Results: Prospective follow-up exposed an occurrence of seroconversion of $12.1 \%$ during study duration. On multivariate analysis, both increase in the duration on hemodialysis besides attending more than one centre for $H D$ were significantly associated with anti-HCV positivity ( $p<0.05$, OR 0.185), ( $p<0.05$, OR 4.52) respectively. Risk factors blood transfusion and AST $>40 \mathrm{IU} / \mathrm{L}$ also shows significant association for seroconversion $(p<0.05)$.

Conclusion: It is concluded that increase post dialysis incidence of HCV occurs as specific guidelines for HCV infected patients were not followed. Regular surveillance for HCV infection helps dramatically in decreasing the spread of HCV in hemodialysis unit.
\end{abstract}

\section{INTRODUCTION}

Hepatitis C virus (HCV) infection is significant cause of morbidity and mortality in hemodialysis patients ${ }^{1 \& 2}$ and observed as major public health problem ${ }^{3 \& 4}$ infecting 170 million people globally ${ }^{5}$. Patients who undergo maintenance hemodialysis (HD) treatment are at increased hazard of getting these infections and have a greater prevalence of HCV than the general population ${ }^{6-9}$. Preceding current screening of blood donors, blood transfusions was related with $\mathrm{HCV}$ infection essential to recover the anaemia related with kidney syndrome $^{10 \& 11}$. Multiple blood transfusions and prolonged vascular exposure increase the risk of acquiring blood-borne infections in patients experiencing HD. Among end stage renal disease (ESRD) patients, blood borne virus is predominantly higher because of illicit drug use, inadequate sterilization of medical equipments, invasive dialysis procedures, mode of dialysis, contaminated blood and blood products and duration of end stage kidney disease $^{12-17}$.

Second most recurrent source of $\mathrm{HCV}$ infection is the nosocomial transmission ${ }^{18 \& 19}$. Most incidences of $\mathrm{HCV}$ transmission are consequently due to patient to patient transmission in the hospital setting through invasive procedures, such as sharing of multi dose vials, sharing of dialysis equipment, insertion of an intravascular catheter, surgery and colonoscopy ${ }^{20-24}$. Inadvertent bacteria transmission to patients through environmental surfaces, contact with contaminated HD equipments and supplies during treatment ${ }^{25 \& 26}$, use of multi dose medication vials, regular use 
of recombinant human erythropoietin and staff members has been revealed as the most significant cause of $\mathrm{HCV}^{27 \& 28}$. With this background, the current study aims to determine the incidence and possible risk factors of $\mathrm{HCV}$ infection in renal disease patients undergoing HD in tertiary care hospital of Pakistan.

\section{METHODOLOGY}

\section{Study setting}

This descriptive observational study was performed in HD centre of a tertiary care hospital treating adult Chronic kidney disease (CKD) patients from January to October 2018.

\section{Study design}

Patient demographics and medical information were attained from patient's medical record such as patient's age, gender, level of education, type and stage of kidney disease, HD period, therapeutic history and sero-positivity to HD along $\mathrm{HCV}$ with laboratory results. HCV sero-positivity was termed as: identification of HCV antibodies by third generation enzyme linked immunoassay (ELISA). In limited laboratories, tests were carried out. Furthermore, all CKD patients undergoing HD per shift were investigated for during study period about further probable risk factors for HCV infection. These comprised of associated comorbidity, status of anaemia treatment, HCV status of sexual partner, history of blood transfusions (number and time of blood transfusion) and history of visits to another dialysis centre for hemodialysis. Data related to infection control procedures was also obtained from HD unit.

During follow-up, observe and identify seroconversion to $\mathrm{HCV}$ in already seronegative patients was carried out. This step covered a cohort of $173 \mathrm{CKD}$ patients from a single tertiary care hospital. All seroconversions were documented and comprised whether the patient was transplanted or expired. All HD patients were observed to guarantee the inclusion of every new seroconversion during the study duration and to approve the positive results; all new seroconversions were retested.

\section{Ethical approval of study}

Permission to carry out the study was approved from the respective tertiary care on their letter head and signed from respective authorities. The project was permitted by the Bio-Ethics Committee of research institute. Patients were included in the study after taking written informed consent.

\section{Statistical Investigation}

Information were accomplished and evaluated using SPSS version 2.1 (IBM). A multinomial logistic regression (MLR) model was used to investigate the possible predictors for $\mathrm{HCV}$ seroconversion. Study was emphasised on patients with seroconversion compared to patients with no conversion in their status to classify the reasons causative of seroconversion throughout the dialysis treatment. Independent variables included number of blood transfusions, haemodialysis duration, number of altered haemodialysis units visited for cure and lab values of ALT and AST were entered in the model. Alpha was fixed at $5 \%$ level.

\section{RESULTS AND DISCUSSION}

\section{Results \\ Influencing factors}

One hundred seventy three participants undergo haemodialysis during the study duration. The mean age of the HD patients included was 46.4 years $(S D \pm 13.37)$ and the age range was 16 to 71 years. Among those $15.6 \%$ of the patients were of $18-30$ years, $28.9 \%$ of $31-45$ years, $42.2 \%$ of $46-60$ years and $13.3 \%$ of $61-75$ years. The highest numbers of ESRD incidences were seen in the patient with advanced age (46-60). Just over half $(63.6 \%)$ of the participants were male and most $(83.8 \%)$ married. The majority of people were those who suffer from chronic kidney disease have low education level (72.3\%).

Based on HD treatment duration, from which $13.3 \%$ undergoing HD from 3 months and $86.7 \%$ from $>3$ months (ranging from three to 60 months). Study included those participants who were $100.0 \%$ HCV negative before the initiation of $\mathrm{HD}$ and all of the patients undergoing HD were of chronic renal failure. None of the patient was co-infected by HCV and HBV. Over half $(56.6 \%, 98 / 173)$ of all patients had conventional blood transfusions and $50.9 \%$ (88/173) were known to have received management at different $\mathrm{HD}$ units. 
Causes of ESRD included hypertension, diabetes mellitus and other unknown causes, among which $(55.5 \%, 96 / 173)$ participants had two or less than two comorbid condition while
$(44.5 \%, 77 / 173)$ had more than two comorbidities. Table 1 illustrate the demographics of the studied people consequently.

Table 1: Characteristics of haemodialysis patients and evaluation of factors associated with seroconversion during dialysis treatment by regression analysis $(n=173)$.

\begin{tabular}{|c|c|c|c|c|c|}
\hline \multirow{2}{*}{$\begin{array}{l}\text { Patient medical } \\
\text { information }\end{array}$} & & \multirow{2}{*}{$\begin{array}{l}\text { HCV negative } \\
\mathrm{N}(\%), n=152\end{array}$} & \multirow{2}{*}{$\begin{array}{c}\text { Seroconversion } \\
\text { to } \mathrm{HCV} \text { positive } \\
\mathrm{N}(\%), n=21\end{array}$} & \multicolumn{2}{|c|}{ Multi logistic } \\
\hline & & & & $\begin{array}{c}\text { OR } \\
\text { (odds-ratio) }\end{array}$ & $p$-value \\
\hline Age groups & $\begin{array}{l}18-30 \\
31-45 \\
46-60 \\
61-75 \\
\end{array}$ & $\begin{array}{l}25(16.4) \\
42(27.6) \\
66(43.4) \\
19(12.5) \\
\end{array}$ & $\begin{array}{l}2(9.5) \\
8(38.1) \\
7(33.3) \\
4(19.0) \\
\end{array}$ & $\begin{array}{l}0.095 \\
0.625 \\
0.497 \\
0.997 \\
\end{array}$ & $\begin{array}{l}\mathbf{0 . 0 0 6} \\
0.708 \\
0.609 \\
0.998 \\
\end{array}$ \\
\hline Gender & $\begin{array}{l}\text { Male } \\
\text { Female } \\
\end{array}$ & $\begin{array}{l}95(62.5) \\
57(37.5) \\
\end{array}$ & $\begin{array}{c}15(71.4) \\
6(28.6) \\
\end{array}$ & 1.609 & 0.400 \\
\hline Marital status & $\begin{array}{l}\text { Married } \\
\text { Unmarried } \\
\end{array}$ & $\begin{array}{l}127(83.6) \\
25(16.4) \\
\end{array}$ & $\begin{array}{c}18(85.7) \\
3(14.3) \\
\end{array}$ & 0.158 & 0.171 \\
\hline Education & $\begin{array}{l}\text { Educated } \\
\text { Uneducated }\end{array}$ & $\begin{array}{c}43(28.3) \\
109(71.7) \\
\end{array}$ & $\begin{array}{c}5(23.8) \\
16(72.6) \\
\end{array}$ & 0.332 & 0.165 \\
\hline Employment & $\begin{array}{l}\text { Employed } \\
\text { Unemployed }\end{array}$ & $\begin{array}{c}15(9.9) \\
137(90.1)\end{array}$ & $\begin{array}{c}5(23.8) \\
16(72.6) \\
\end{array}$ & 5.556 & 0.036 \\
\hline $\begin{array}{l}\text { Hemodialysis } \\
\text { duration }\end{array}$ & $\begin{array}{l}3 \text { months } \\
>3 \text { months }\end{array}$ & $\begin{array}{c}23(15.1) \\
129(84.9) \\
\end{array}$ & $\begin{array}{c}7(33.3) \\
14(66.7) \\
\end{array}$ & $\begin{array}{l}0.629 \\
0.185 \\
\end{array}$ & $\begin{array}{l}0.434 \\
\mathbf{0 . 0 0 0} \\
\end{array}$ \\
\hline $\begin{array}{l}\text { Associated } \\
\text { comorbidity }\end{array}$ & $\begin{array}{l}<2 \text { or } 2 \text { morbidities } \\
>2 \text { morbidities }\end{array}$ & $\begin{array}{l}85(55.9) \\
67(44.1) \\
\end{array}$ & $\begin{array}{l}11(52.4) \\
10(47.6) \\
\end{array}$ & $\begin{array}{l}0.939 \\
1.040\end{array}$ & $\begin{array}{l}0.129 \\
0.149\end{array}$ \\
\hline $\begin{array}{l}\text { Anaemia } \\
\text { treatment }\end{array}$ & $\begin{array}{l}\text { Blood transfusion } \\
\text { Erythropoietin } \\
\text { treatment } \\
\text { Blood transfusion \& } \\
\text { erythropoietin }\end{array}$ & $\begin{array}{c}13(8.6) \\
74(48.7) \\
65(48.2)\end{array}$ & $\begin{array}{l}3(14.3) \\
3(14.3) \\
15(71.4)\end{array}$ & $\begin{array}{l}0.684 \\
0.150\end{array}$ & $\begin{array}{l}0.620 \\
0.006\end{array}$ \\
\hline $\begin{array}{l}\text { No. of Blood } \\
\text { transfusions }\end{array}$ & $\begin{array}{l}<5 \text { or }=5 \\
>5\end{array}$ & $\begin{array}{l}34(22.4) \\
43(28.3) \\
\end{array}$ & $\begin{array}{c}5(23.8) \\
15(71.4) \\
\end{array}$ & $\begin{array}{l}0.147 \\
0.349 \\
\end{array}$ & $\begin{array}{l}0.000 \\
0.000\end{array}$ \\
\hline $\begin{array}{l}\begin{array}{l}\text { Vaccination for } \\
\text { hepatitis B }\end{array} \\
\end{array}$ & $\begin{array}{l}\text { No } \\
\text { Yes } \\
\end{array}$ & $\begin{array}{c}52(34.2) \\
100(65.8) \\
\end{array}$ & $\begin{array}{c}6(28.6) \\
15(71.4) \\
\end{array}$ & $\begin{array}{l}0.121 \\
0.171 \\
\end{array}$ & $\begin{array}{l}0.152 \\
0.208 \\
\end{array}$ \\
\hline Recent surgery & $\begin{array}{l}\text { No } \\
\text { Yes }\end{array}$ & $\begin{array}{l}131(86.2) \\
21(13.8)\end{array}$ & $\begin{array}{c}7(33.3) \\
14(66.7)\end{array}$ & 0.113 & 0.000 \\
\hline $\begin{array}{l}\text { Screening of } \\
\text { blood donor }\end{array}$ & $\begin{array}{l}\text { Yes } \\
\text { Don't know } \\
\text { No donor } \\
\end{array}$ & $\begin{array}{l}58(38.2) \\
19(12.5) \\
75(49.3) \\
\end{array}$ & $\begin{array}{c}9(42.9) \\
11(52.4) \\
1(4.8) \\
\end{array}$ & $\begin{array}{l}5.662 \\
21.33\end{array}$ & $\begin{array}{l}0.121 \\
\mathbf{0 . 0 0 6}\end{array}$ \\
\hline $\begin{array}{l}\text { Family history of } \\
\mathrm{HCV}\end{array}$ & $\begin{array}{l}\text { Negative } \\
\text { positive }\end{array}$ & $\begin{array}{l}131(86.2) \\
21(13.8) \\
\end{array}$ & $\begin{array}{l}12(57.1) \\
9(42.9) \\
\end{array}$ & 0.443 & 0.173 \\
\hline 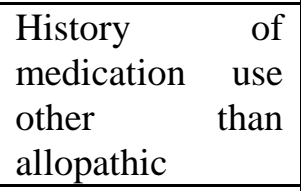 & $\begin{array}{l}\text { No } \\
\text { Yes }\end{array}$ & $\begin{array}{l}90(59.2) \\
62(40.8)\end{array}$ & $\begin{array}{c}8(38.1) \\
13(61.9)\end{array}$ & 1.271 & 0.702 \\
\hline $\begin{array}{lr}\begin{array}{l}\text { History of } \\
\text { piercing and } \\
\text { acupuncture }\end{array} \\
\end{array}$ & $\begin{array}{l}\text { No } \\
\text { Yes }\end{array}$ & $\begin{array}{c}137(90.1) \\
15(9.9)\end{array}$ & $\begin{array}{l}17(81.0) \\
4(19.0)\end{array}$ & 0.939 & 0.933 \\
\hline
\end{tabular}


Study revealed that seroconversion occurred in 21 patients out of 173 patients $(12.1 \%)$ among which $38.1 \%$ were of $31-45$ years of age, majority of them were male $(71.4 \%)$ and $85.7 \%$ were married, even though no variations were detected in $\mathrm{HCV}$ infection status of remaining 152 patients. Seroconversion was not considerably related with sexual characteristics and marital status of the patient. In age groups of the participants only 18-30 year of age showed significant association ( $p=0.006$, OR 0.095 , CI 0.018 0.508 ) while advancing age proven to be a risk factor for seroconversion ( $p>0.05$, OR 0.625 , CI 0.053-7.32). HBV vaccine had been directed in 115 of 173 patients how ever post vaccination antibody levels were not tested. HBV immunization showed non-significant association with seroconversion status ( $p>$ $0.05)$. Vaccination was routinely practiced at the unit, $71.4 \%$ seroconverted patients were vaccinated.

\section{Risk factors for $\mathrm{HCV}$ infection}

With HCV seroconversion risk factors (vulnerable sexual interaction, inoculating drug use, history of recent surgery, sharing of tooth brush, barber use of shave blade and tattooing) were not considerably related. Out of 21 seroconverted patients, 9 (42.9\%) described to have HCV positive sexual companion. Since HCV spread through blood and blood products and blood transfusion is one of the most important possible factor in $\mathrm{HCV}$ transmission. In our present study, $15(71.4 \%)$ out of 21 seroconverted patients had received beyond 5 times of blood transfusion, remaining $23.8 \%$ were received less than 5 transfusions. Seroconversion was greater in patients with history of blood transfusion and seroconverted patients were considerably more probably have received greater number of blood transfusions $(p=0.000$, OR $0.349,95 \%$ CI $0.194-0.628)$ and significantly more likely to have more than two altered HD units ( $p=0.000$, OR 4.52, CI 2.767.40) compared with HCV negative patients.

A majority of the patients $(52.4 \%)$ were unfamiliar about the effective screening of blood donor. Poor blood donor screening was observed as risk factor for HCV acquisition ( $p=$ 0.06, OR 21.3 CI 2.3-192.7). Based on the duration of $\mathrm{HD}, 14(66.7 \%)$ out of seroconverted patients undergo HD for $>3$ months so the hemodialysis duration was significantly longer in patients with seroconversion $(p=0.000$, OR 0.185 , CI 0.08 0.38 ). As described in table 2 , a non-significant relationship ( $p>0.05)$ was detected among the hazard of seroconversion with a history of associated comorbidity, piercing and acupuncture, history of medication use other than allopathic, as well as family history of $\mathrm{HCV}$ of study participants.

The higher levels of aspartate amino transferase (AST) and alanine transaminase (ALT) were observed in $12.1 \%(21 / 173)$ of study participants. AST $>40 \mathrm{IU} / \mathrm{L}(p=0.000$, OR 0.927, CI 0.889-0.967) and ALT >56 IU/L $(p=0.009$, OR 1.051, CI 1.013-1.091) were associated with $\mathrm{HCV}$ positivity.

Table 2: Association between AST, ALT and HCV infection.

\begin{tabular}{|l|c|c|c|}
\hline \multicolumn{2}{|c|}{ Variables } & \multicolumn{2}{c|}{ Multi-logistic } \\
\hline & Mean \pm S.D & OR (odds-ratio) & $p$-value \\
\hline Dialysis from other centre & $-0.156 \pm 0.945$ & 4.523 & 0.000 \\
\hline ALT levels & $26.66 \pm 28.40$ & 1.051 & 0.009 \\
\hline AST levels & $26.16 \pm 23.38$ & 0.927 & 0.000 \\
\hline
\end{tabular}




\section{Discussion}

The current study assessed HCV seroconversion in ESRD patients undergoing HD and its association with risk factors and facility specific practice patterns. In patients receiving HD treatment, the seroconversion rate for $\mathrm{HCV}$ infection and incidence of anti$\mathrm{HCV}$ antibodies is remarkably much higher than the general population ${ }^{16 \& 29}$. Our study reports that 21 seroconversion for $\mathrm{HCV}$ infection during study duration through eventual follow-up of sero-negative HD patients providing a general incidence of $12.1 \%$ of total patients. In Libya, high occurrence of new HCV infections (7.2\%) was observed during 1 year surveillance period ${ }^{6}$.

In present study the prevalence rate of seroconversion was found to be higher among men than women and in employed, older patients. One mustproceed into consideration that this concluding study had a relatively less sample size $(n=173)$ and all patients were recruited from a distinct HD centre ${ }^{7}$.

Our study shows that ESRD patients of 18-30 years of age revealed significant association with seroconversion while greater incidence of HCV sero-positivity was observed in elder patients of age 31-75. On average older age prove to be a best predictor for acquiring HCV infection in patients undergo HD treatment. This observation is in agreement with other studies ${ }^{30 \& 31}$.

Conversely $\mathrm{HCV}$ seroconversion was significantly associated with length of time on HD. Study participants undergo hemodialysis for longer duration was more prone towards $\mathrm{HCV}$ acquisition. It is dependable with nosocomial spread associated to dialysis, meanwhile extensive duration of dialysis treatment signifies a longer period at hazard of attaining an infection. Related observation have been stated by different authors ${ }^{5}$. Another study in 2006 showed that in HD patients the frequency of $\mathrm{HCV}$ was associated with longer period of HD therapy, this study also revealed that those $\mathrm{HCV}$ negative patients who have longer period of HD treatment became seroconverted. These results are compatible with the findings of other studies ${ }^{2,29,32-34}$. It is of vital importance to prevent nosocomial transmission in Pakistan such as HCV antiviral treatment is costly and its accessibility is restricted to only limited centres.
On the other hand ESRD patients require blood transfusion and erythropoietin for anaemia treatment ${ }^{10}$, study revealed that patients receiving erythropoietin treatment only are less susceptible towards acquiring $\mathrm{HCV}$ whereas a progressive history of blood transfusions along with number of blood transfusions was identified as risk factor for HCV spread. Strong association of blood transfusion with $\mathrm{HCV}$ infection was reported by other studies ${ }^{7 \& 35}$. In transmission of $\mathrm{HCV}$ infection through contaminated needles or syringes and blood transfusion, medical interventions play the most important role ${ }^{18}$.

Our study reported that a greater percentage of patients had formerly received blood transfusions without effective screening of blood donor (52.4\%). In agreement with other studies HCV infection was further predominant in patients with poor screening of donor blood $^{6 \& 19}$. Moreover it is probable that approximate blood donors with $\mathrm{HCV}$ infection are being neglected by present screening measures and these may possibly essential to be re-evaluated.

Current study indicates there is a significant association of $\mathrm{HCV}$ infection with a history of HD from alternative centres. For social reasons many patients travel but after starting dialysis some also moved to another dialysis centre as an emergency providing acute services. HBV infection relationship with travel proposes the hazard of nosocomial infection during follow up of seroconverted patients. Other studies supports this incidence ${ }^{2,6,20 \& 36}$. These interpretations highlight the significance of separating patients following their return and observing them for seroconversion.

On the other hand the use of Multidose vials was mutual and is probable to have been an essential basis of nosocomial infections. Without being vaccinated against HBV many patients started HD treatment. Even the antibody level was not evaluated in vaccinated patients.

For seroconverted patients, mean values for ALT and AST were greaterin spite of being within the normal range. $\mathrm{HCV}$ infections are related with increased transaminase levels ${ }^{10 \& 19}$. Nevertheless in CD patients with viral hepatitis infection, elevation of transaminases $(>40$ $\mathrm{IU} / \mathrm{L})$ is not permanently exist ${ }^{37}$. AST $>40$ 
shows significant association with $\mathrm{HCV}$ infection. This recommends that an inexplicable or minorrise in AST could be used to indicate initial HCV seroconversion.

Several behaviours like for each patient changing gloves after touching HD machines, paying careful attention to hand hygiene after contact with different patients, complete disinfection of HD machines, and declining the use of blood products to the minimum level are suggested to avoid transmission of blood borne infections. Some breaches in infection control practices were identified through investigation of local records. Particularly there was no risk valuation for infection prevention and no explicit control programmes for the dialysis facility as well as education and training of nursing staff were estimated inadequate. Written procedures for cleaning and sterilization of environmental surfaces and for safe direction of parenteral medication were missing. HCV infection was said to be scrutinized but written practices on $\mathrm{HCV}$ screening and the role of infection control units on management of patients who seroconverted were not accessible.

\section{Study limitation}

Some boundaries of this study ought to be agreed. Repeatedly incomplete medical histories and further clinical facts was regularly attained by questioning HD staff and patients. In local laboratories serological analysis was performed and it is probable that there was variance in the quality of testing. To detect anti-HCV antibodies, HCV testing depend on a third generation ELISA and was not established by the finding of HCV RNA in blood samples. Genotyping or validation with PCR is presently not accessible in maximum centres. This study also reported that seroconversion was most likely to occur in patients undergo HD greater than three months Though, serologic assessments were not done frequently in every patient, consequently these outcomes are subjective as the infection might be done far ahead.

\section{Conclusion}

This study concluded that patients on continuous HD treatment have a high prevalence and incidence of $\mathrm{HCV}$ infection. Study revealed post dialysis occurrence of
HCV within HD units. Vital action is required in HD centres to enhance and develop infection control actions and to diminish reliance on blood transfusions aimed at the management of anaemia. Regular surveillance for $\mathrm{HCV}$ infection helps significantly in decreasing the spread of HCV in HD unit. Poor practices of nursing staff and high level of non-adherence to infection control strategies were observed. Adherence of health care workers to infection control competencies can be improved by providing continuous education, supervision and monitoring

\section{Acknowledgements}

We are obliged to our collaborators $\mathrm{Dr}$ Zain, Head of Urology Department, Dr Ali and Dr Sharjil for data assistance along with healthcare team in dialysis unit for their support. The authors are also profoundly grateful to the patients who participated in the study.

\section{Informed consent}

Informed consent was obtained from all individual participant included in the study.

\section{REFERENCES}

1- R. Minutolo, A. Aghemo, A. Chirianni, F. Fabrizi, L. Gesualdo, E. G. Giannini, P. Maggi et al. "Management of hepatitis C virus infection in patients with chronic kidney disease: Position statement of the joint committee of Italian association for the study of the liver (AISF), Italian society of internal medicine (SIMI), Italian society of infectious and tropical disease (SIMIT) and Italian society of nephrology (SIN)", Internal and Emergency Medicine, 13 (8), 1139-1166 (2018).

2- K. Aman, S. A. Al-Dubai, R. Aman, A. Hawash, M. Alshagga and S Kassim, "Prevalence and associated factors of hepatitis $\mathrm{C}$ virus infection among renal disease patients on maintenance hemodialysis in three health centers in Aden, Yemen: A cross sectional study", Saudi J. Kidney Dis. Transpl., 26 (2), 380-5 (2015).

3- N. Khattak, A. Afridi, I. Ud Din, S. Ullah, S. Nisar and Z. Kibria, "Frequency of 
hepatitis B in hemodialysis patients in lady reading hospital Peshawar, Khyber Pakhtunkhwa", Journal of Medical Sciences, 28 (2), 158-161 (2020).

4- S. Senatore, C. Galli, A. Conti, M. Faccini, S. Cantoni, G. Ciconali, et al., "Hepatitis C virus outbreak in a haemodialysis unit: learning from failures", J. Hosp. Infect., 94 (3), 249-52 (2016).

5- S. Mahmud, V. Akbarzadeh and L. J. AbuRaddad, "The epidemiology of hepatitis C virus in Iran: systematic review and metaanalyses", Scientific Reports, 8 (1), 1-25 (2018).

6- W. A. Alashek, C. W. McIntyre and M. W. Taal, "Hepatitis B and C infection in haemodialysis patients in Libya: prevalence, incidence and risk factors", BMC Infect. Dis., 12, 1-8 (2012).

7- B. N. Vilas, P. R. Lyra and D. Venkatesha, "Prevalence of hepatitis $C$ virus infection among chronic liver disease patients in a tertiary care hospital", Int. J. Curr. Microbiol. Appl. Sci., 7 (02), 2489-93 (2018).

8- F. Fabrizi, P. Martin, V. Dixit and P. Messa, "Hepatitis $\mathrm{C}$ virus infection and kidney disease: A meta-analysis", Clin. J. Am. Soc. Nephrol., 7 (4), 549-57 (2012).

9- F. Fabrizi, F. F. Poordad and P. Martin, "Hepatitis $\mathrm{C}$ infection and the patient with end-stage renal disease", Hepatology, 36 (1), 3-10 (2002).

10- N. Çelik, O. Çelik, C. Sevinç and O. Ünal, "Hepatitis C prevalence in hemodialysis patients and the results of new antiviral therapy", Turk. J. Nephrol., 28 (2), 103-8 (2019).

11- N. S. Constancio, M. L. G. Ferraz, C. T. B. Martins, A. C. Kraychete, P. L. Bitencourt and M. M. do Nascimento, "Hepatitis C in hemodialysis units: Diagnosis and therapeutic approach", Brazilian Journal of Nephrology, 41 (4), 539-549 (2019).

12- C. Isnard Bagnis, C. Couchoud, M. Bowens, A. Sarraj, G. Deray, J. Tourret, et al., "Epidemiology update for hepatitis $\mathrm{C}$ virus and hepatitis B virus in end-stage renal disease in France", Liver Int., 37 (6), 820-6 (2017).
13- Y. Su, J. L. Norris, C. Zang, Z. Peng and $\mathrm{N}$. Wang, "Incidence of hepatitis $\mathrm{C}$ virus infection in patients on hemodialysis: A systematic review and meta-analysis", Hemodial. Int., 17 (4), 532-41 (2013).

14- C. Amira and O. Lesi, "Seroprevalence of hepatitis $\mathrm{B}$ and $\mathrm{C}$ infection among Nigerian subjects with chronic kidney disease", J. Clin. Sci., [Internet], 14 (2), 58 (2017). Available from: http://www.jcsjournal.org/text.asp?2017/1 4/2/58/204700.

15- T. G. Wreghitt, "Blood-borne virus infections in dialysis units - A review", Rev. Med. Virol., [Internet], 9 (2), 101-9 (1999). Available from: http://www.ncbi. nlm.nih.gov/entrez/query.fcgi?cmd=Retrie ve $\& \mathrm{db}=$ PubMed $\&$ dopt $=$ Citation\&list_uids $=10386337 \% 5 \mathrm{Cnhttp}: / / \mathrm{www} \cdot$.ncbi.nlm.nih. gov/pubmed/10386337.

16- J. Sandhu, J. K. Preiksaitis, P. M. Campbell, K. C. Carriere and P. A. Hessel, "Hepatitis $\mathrm{C}$ prevalence and risk factors in the northern Alberta dialysis population", Am. J. Epidemiol., 150 (1), 58-66 (1999).

17- M. C. Nito, S. A. Draibe, A. E. B. Silva, M. L. Ferraz, C. Granato, C. A. P. Pereira, et al., "Nephrology dialysis transplantation incidence of and risk factors for hepatitis B virus and hepatitis C virus infection among haemodialysis and CAPD patients", Evidence for Environmental Transmission, (282), 240-6 (2018).

18- E. Girou, S. Chevaliez, D. Challine, M. Thiessart, Y. Morice, P. Lesprit, et al., "Determinant roles of environmental contamination and noncompliance with standard precautions in the risk of hepatitis $\mathrm{C}$ virus transmission in a hemodialysis unit", Clin. Infect. Dis., [Internet], 47 (5), 627-33 (2008). Available from: https://academic.oup.com/ cid/article-lookup/doi/10.1086/590564.

19- C. M. Duong, D. P. Olszyna and M-L. McLaws, "Hepatitis B and C virus infections among patients with end stage renal disease in a low-resourced hemodialysis center in Vietnam: a crosssectional study", BMC Public Health, [Internet], 15 (1), 192 (2015). Available from: http://bmcpublichealth.biomedcentral.com/articles/10.1186/s12889-0151532-9. 
20- Y. Su, R. Yan, Z. Duan, J. L. Norris, L. Wang, Y. Jiang, et al., "Prevalence and risk factors of hepatitis $\mathrm{C}$ and $\mathrm{B}$ virus infections in hemodialysis patients and their spouses: A multicenter study in Beijing", China. J. Med. Virol., [Internet], 85 (3), 425-32 (2013). Available from: https://www.ncbi.nlm.nih. gov/pubmed/23341370.

21- C. Sartor, P. Brunet, S. Simon and C. Tamalet, "Transmission of hepatitis $\mathrm{C}$ virus between hemodialysis patients sharing the same machine", Infect. Control. Hosp. Epidemiol., 25 (7), 609-11 (2004).

22- N. Furusyo, N. Kubo and H. Nakashima, "Confirmation of nosocomial hepatitis $\mathrm{C}$ virus infection in a hemodialysis unit", ibid., 25 (7), 584-90 (2014).

23- C. M. Duong and M. L. McLaws, "An investigation of an outbreak of hepatitis $\mathrm{C}$ virus infections in a low-resourced hemodialysis unit in Vietnam", $\boldsymbol{A m}$. $\boldsymbol{J}$. Infect. Control., [Internet], 44 (5), 560-6 (2016). Available from: http://dx.doi. org/10.1016/j.ajic.2016.01.014.

24- P. M. Schneeberger, I. Keur, A. M. van Loon, D. Mortier, K. O. de Coul, A. V. van Haperen, et al., "The prevalence and incidence of hepatitis $\mathrm{C}$ virus infections among dialysis patients in the Netherlands: a nationwide prospective study", J. Infect. Dis., [Internet], 182 (5), 1291-9 (2000). Available from: http://www.ncbi.nlm.nih.gov/pubmed/110 23452.

25- S. Jasuja, A. K. Gupta, R. Choudhry, V. Kher, D. K. Aggarwal, A. Mishra, et al., "Prevalence and associations of hepatitis $\mathrm{C}$ viremia in hemodialysis patients at a tertiary care hospital", Indian J. Nephrol., 19 (2), 62-7 (2009).

26- A. W. Tu, J. A. Buxton, M. Whitlock, O. Djurdjev, M. Chong, M. Krajden, et al., "Prevalence and incidence of hepatitis $\mathrm{C}$ virus in hemodialysis patients in British Columbia: Follow-up after a possible breach in hemodialysis machines", Can. J. Infect. Dis. Med. Microbiol., 20 (2), 1924 (2009).
27- P. Bhaumik and K. Debnath, "Prevalence of hepatitis $\mathrm{B}$ and $\mathrm{C}$ among hemodialysis patients of Tripura, India", J. P. Journals, 10-3 (1993).

28- F. Yakaryilmaz, O. Alp Gurbuz, S. Guliter, A. Mert, Y. Songur, T. Karakan, et al., "Prevalence of occult hepatitis B and hepatitis $\mathrm{C}$ virus infections in Turkish hemodialysis patients", Ren. Fail., 28 (8), 729-35 (2006).

29- M. Sampietro, S. Badalamenti, S. Salvadori, N. Corbetra, G. Gizii, G. Como, et al., "High prevalence of a rare hepatitis $\mathrm{C}$ virus in patients treated in the same hemodialysis unit: Evidence for nosocomial transmission of HCV", Kidney International, 47, 911-7 (1995).

30- A. Saxena and B. Panhotra, "The vulnerability of middle - aged and elderly patients to hepatitis c virus infection in a high-prevalence hospital - based hemodialysis setting", J. Am. Geriatr. Soc., [Internet], 242-6 (2004). Available from: http://onlinelibrary.wiley.com/doi/ 10.1111/j.1532-5415.2004.52062.x/full.

31- A. A. Mostaghni, A. Soltanian, E. Mokhtari, S. Japoni and D. Mehrabani, "Seroprevalence of hepatitis B virus among hemodialysis patients in Bush-ehr province, southern Iran", Hepatitis Monthly, 11 (3), 200-2 (2011).

32- S. Savaj, E. Abdi, H. Nejadgashti, S. Eris, et al., "Posttransplant diabetes mellitus in kidney allograft recipients at Shaheed Hasheminejad Hospital", Iran J. Kidney Dis., 2 (1), 46-49 (2008).

33- M. M. Ansar and A. Kooloobandi, "Prevalence of hepatitis $\mathrm{C}$ virus infection in thalassemia and haemodialysis patients in north Iran-Rasht", Journal of Viral Hepatitis, 50, 390-2 (2002).

34- M. Al-Jamal, A. Al-Qudah, K. F. AlShishi, A. Al-Sarayreh and L. Al-Quraan, "Hepatitis C virus (HCV) infection in hemodialysis patients in the south of Jordan", Saudi J. Kidney Dis. Transpl., 20 (3), 488-92 (2009)

35- C. L. van der Poel, H. W. Reesink, W. Schaasberg, A. Leentvaar-Kuypers, E. Bakker, P. J. Exel-Oehlers and P. N. Lelie, "Infectivity of blood seropositive for hepatitis C virus antibodies", Lancet, 335 (8689), 558-60 (1990). 
36- M. H. Somi, M. R. Ardalan, H. Sokhanvar, S. Farhang and A. Pouri, "Hepatitis $\mathrm{C}$ virus infection in dialysis centers of Tabriz, Iran: A multicenter study", Arch. Clin. Infect. Dis., 2 (1), 236 (2007).

37- K. Yasuda, K. Okuda, N. Endo, Y. IshIwatari, R. Ikeda, H. Hayashi, K. Yokozeki, S. Kobayashi and Y. Irie,
"Hypoaminotransferasemia in patients undergoing long-term hemodialysis: Clinical and biochemical appraisal",

Gastroenterology, 109 (4), 1295-300 (1995). 


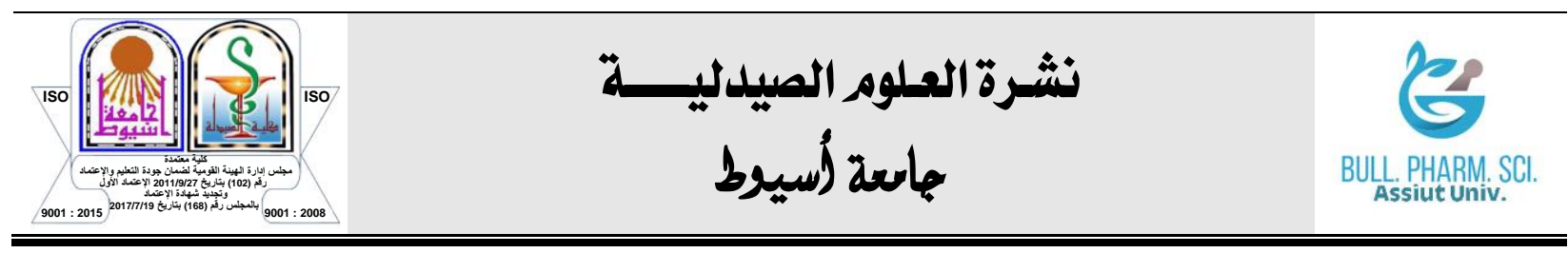

$$
\begin{aligned}
& \text { تنبؤات التحول المصلي للـ HCV بين مرضى الكلى في المرحلة النهائية } \\
& \text { في وحدة غسيل الكلى دين }
\end{aligned}
$$

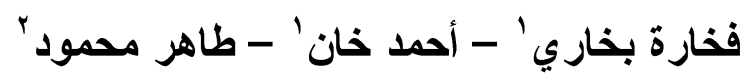

$$
\begin{aligned}
& \text { ' ل قسم الصيدلة ، جامعة القائد الأعظم ، إسلام أباد ، باكستان }
\end{aligned}
$$

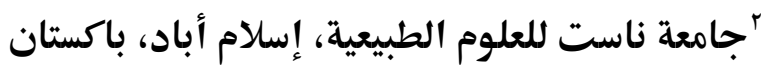

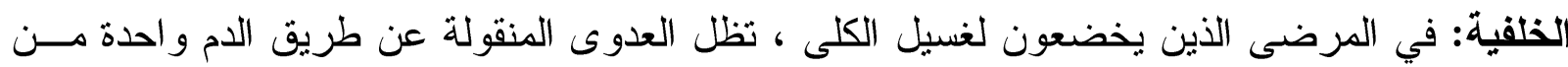

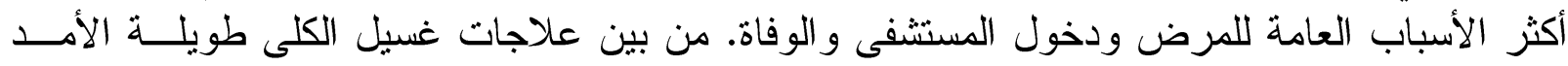

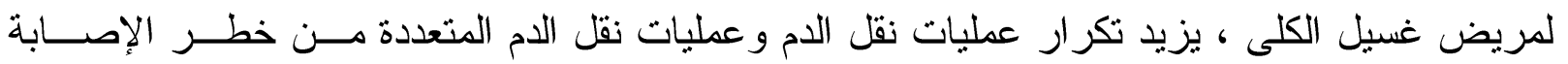
بالعدوى المنقولة بالام.

الهدف: كان الهدف من الدراسة هو تحديد تنبؤات بالتحويل المصلي لفيروس التهاب الكبد الوبائي فـي

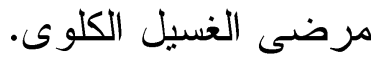

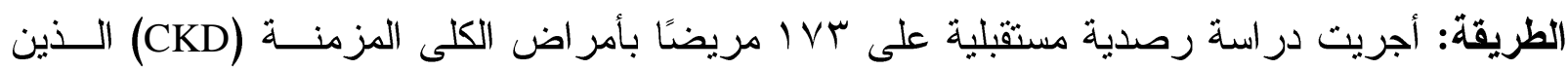

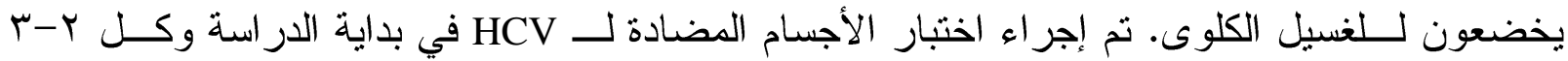
أشهر بعد ذلك. لتحديد الانقلاب المصلي ، تمت مر اقبة المرضى الذين كانو أسلبيين مصليًا لـ ـHCV.

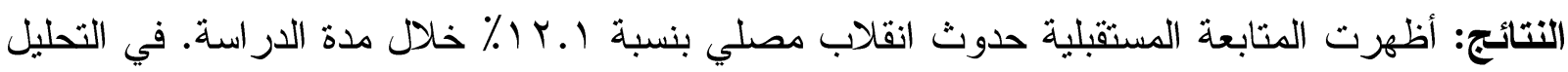

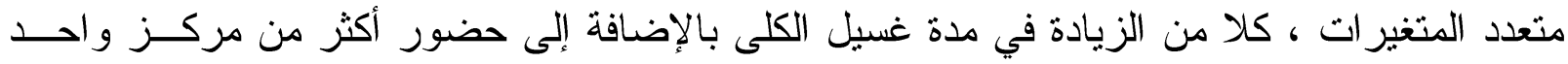

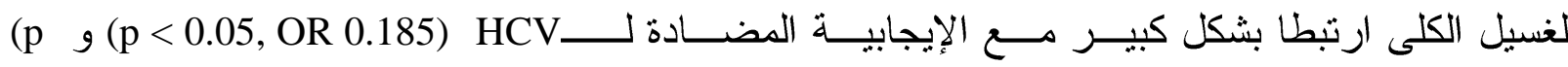

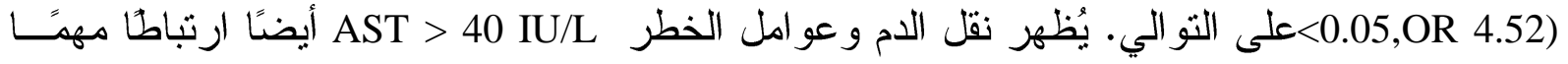

$$
\text { بالانقلاب المصلي (p) (p).05). }
$$

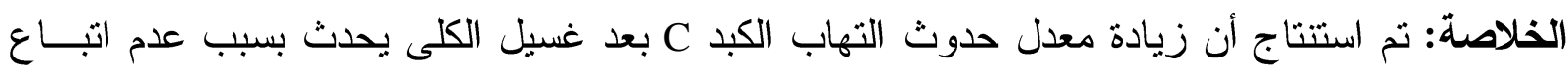

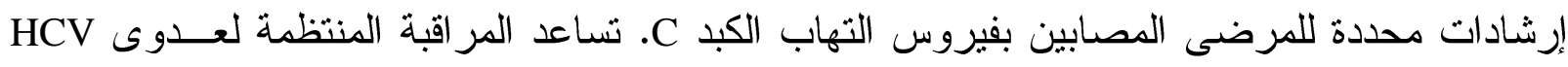
بشكل كبير في تقليل انتشار التهاب الكبد C في وحدة غسيل الكلى. 